\title{
ASSESSING A QUICK MONITORING METHOD USING ROCKY INTERTIDAL COMMUNITIES AS A BIOINDICATOR: A MULTIVARIATE APPROACH IN ALGECIRAS BAY
}

\author{
J. M. GUERRA-GARCÍA*, M. J. MAESTRE, A. R. GONZÁLEZ \\ and J. C. GARCÍA-GÓMEZ \\ Laboratorio de Biología Marina, Departamento de Fisiología y Zoología, Facultad de Biología, \\ Universidad de Sevilla, Avda. Reina Mercedes 6, 41012 Sevilla, Spain \\ (*author for correspondence,e-mail: jmguerra@us.es)
}

(Received 10 November 2004; accepted 18 May 2005)

\begin{abstract}
A multivariate approach was used to test the value of intertidal communities as a bioindicator of environmental conditions at Algeciras Bay, southern Spain. The study area is located in the Strait of Gibraltar and it is subjected to a variety of anthropic impacts. Eight localities (5 inside and 3 outside the bay) were selected, and four transects were undertaken in each locality to characterise the fauna and flora. The spatial distribution of the intertidal species reflected the physico-chemical conditions of Algeciras Bay. The stations located outside the bay, characterised by high hydrodynamism and dissolved oxygen and low sedimentation and turbidity, had a higher diversity and species richness than the inner stations. According to the BIO-ENV procedure and CCA, water turbidity was the factor which best correlated with the intertidal assemblages. SIMPER showed that the molluscs Chtamalus stellatus, Mytilus cf edulis, Littorina neritoides and Balanus perforatus, and the algae Gelidium pusillum, Corallina elongata, Asparagopsis armata, Colpomenia sinuosa and Fucus spiralis were the species that most contributed to the dissimilarity between internal and external sites. The present study, based on the spatial distribution of intertidal taxa, yielded similar results to those previously obtained in the area with costly physico-chemical analysis based on complex matrices of subtidal epifaunal communities. Consequently, the intertidal sampling method proposed in this study is presented here as a quick, effective alternative strategy, and can be useful in environmental monitoring programs, since these communities are easily accessible and amenable to sample, and the sessile nature of the majority of the species makes future, long-term monitoring relatively simple.
\end{abstract}

Keywords: algae, Algeciras Bay, bioindicator, intertidal communities, macrofauna, spatial distribution

\section{Introduction}

Intertidal communities are located at the interface of the land and the sea, and play an important role in maintaining local ecological balance (Cai et al., 2003). They are open ecosystems, with steep environmental gradients and their susceptibility to both terrestrial and marine disturbances makes them more vulnerable than sublittoral and offshore habitats (Thompson et al., 2002).

In comparison with other marine environments, gaining access to intertidal ecosystems is generally easier, and these communities are more amenable to 
management than open ocean habitats. Furthermore, the composition of sessile communities is particularly useful as a baseline for ecological monitoring because such organisms are unable to avoid disturbances in the marine environment and thus, the composition of the community reflects their common history (Fa et al., 2002). However there are still considerable gaps in the available knowledge of these habitats (Thompson et al., 2002).

Algeciras Bay is located in the eastern-most zone of the Strait of Gibraltar (Figure 1). It is an important industrial area, with chemical factories, refineries, thermal power plants, iron works, paper mills and ship yards, along with a major port (Conradi et al., 1997). Recently, several studies have been conducted in Algeciras Bay using subtidal benthic communities as bioindicators (sponges: Carballo et al., 1996; ascidians: Naranjo et al., 1996; epifauna of algae and briozoa: Conradi et al., 1997, Sánchez-Moyano and García-Gómez, 1998; Sánchez-Moyano et al., 2000a, b, 2002). These studies reflected clear differences in community composition between external and internal areas of the Algeciras Bay, showing a good correlation between subtidal fauna and environmental conditions. Although some preliminary results dealing with intertidal communities of Algeciras Bay have been already published (Fa et al., 2003), the value of these communities as a bioindicator has not been tested yet.

The main objective of the present work was a spatial study of the intertidal communities in internal and external sites of Algeciras Bay, to test their value as bioindicator of environmental conditions. Taking into account that, nowdays, authorities and government institutions are demanding quick and effective environmental studies in coastal areas, it seems interesting to focus our efforts on the implementation of a monitoring tool, based on sessile intertidal fauna and flora. The sampling in

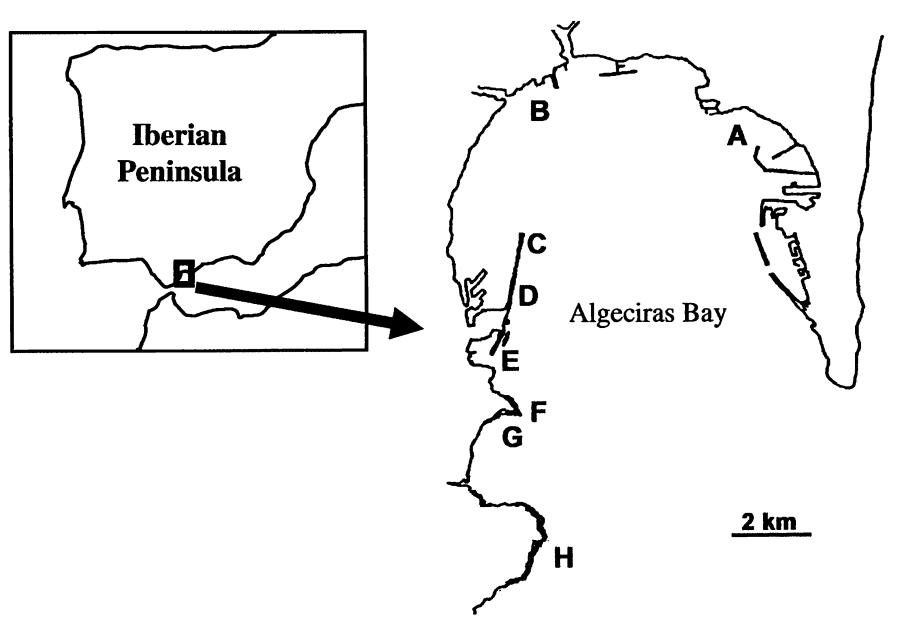

Figure 1. Map of Algeciras Bay showing the sampling localities. A: La Línea; B: Acerinox; C, D: Harbour; E, Saladillo; F, G: San García; H: Punta Carnero. 
these intertidal ecosystems, unlike the previous studies conducted in Algeciras Bay, does not require scuba diving and is potentially useful in environmental monitoring programs since these communities are easily accessible and amenable to sampling. Also, the sessile nature of the majority of the species makes future, long-term monitoring relatively simple.

\section{Materials and Methods}

\subsection{SAMPLING PROCEDURE}

A total of eight sampling sites were selected along the Algeciras Bay (A-H) (Figure 1). Sites A, B, C, D and E are internal areas, while F, G, and H, are external, selected outside the Bay for comparative purposes.

To quantitatively assess changes in abundance and distribution of organisms, a systematic method based on fixed belt transects was selected as the sampling method (see Jones et al., 1980; Fa, 1990). Sampling was conducted during August 2003. At each site, a generalised shore search was previously undertaken in order to both select the most appropriate location for the transects and also to ensure that it was as representative as possible of the area being studied (Fa et al., 2002). Four transects were selected in each site. The stations per transect were marked at $25 \mathrm{~cm}$ intervals. A ruler, set square and rope were used to establish the different heights. The first height was the zero tidal level and the process was continued until the vertical height of 2 meters had been achieved, providing eight stations for each transect (Figure 2). Each station was sampled using quadrats of $25 \times 25 \mathrm{~cm}$, further subdivided into 25 square units of $5 \times 5 \mathrm{~cm}$ with thick fishing line. The presence/absence of both species of algae and macrofauna was recorded for each unit. This method for estimation of abundance using data of presence/absence was employed for all species, to get homogeneous matrices of data instead of mixed matrices of abundances based on density for some species and matrices of cover percentages for others. The census based on presence/absence data was assessed visually on site but if the species could not be properly identified visually, it was removed for later identification in the laboratory. Only the visually distinctive species of algae and macrofauna were considered during sampling. Fa et al. (2002) reported the difficulties of on-site separation of very similar co-existing species such as Mytilus edulis Linnaeus, 1758 and Mytilus galloprovincialis Lamarck, 1819, whose morphs grade into each other. In the present study we have considered Mytilus cf edulis. In addition to the biotic study, several environmental parameters were measured "in situ" in the water column at each sampling site (water temperature, $\mathrm{pH}$, salinity, dissolved oxygen and turbidity). Three measurements were made for each parameter during August and mean values were used for statistical analysis. Water temperature and salinity were measured using a conductivimeter WTW LF-323, and pH using a pHmeter Hanna HI-8324. The 


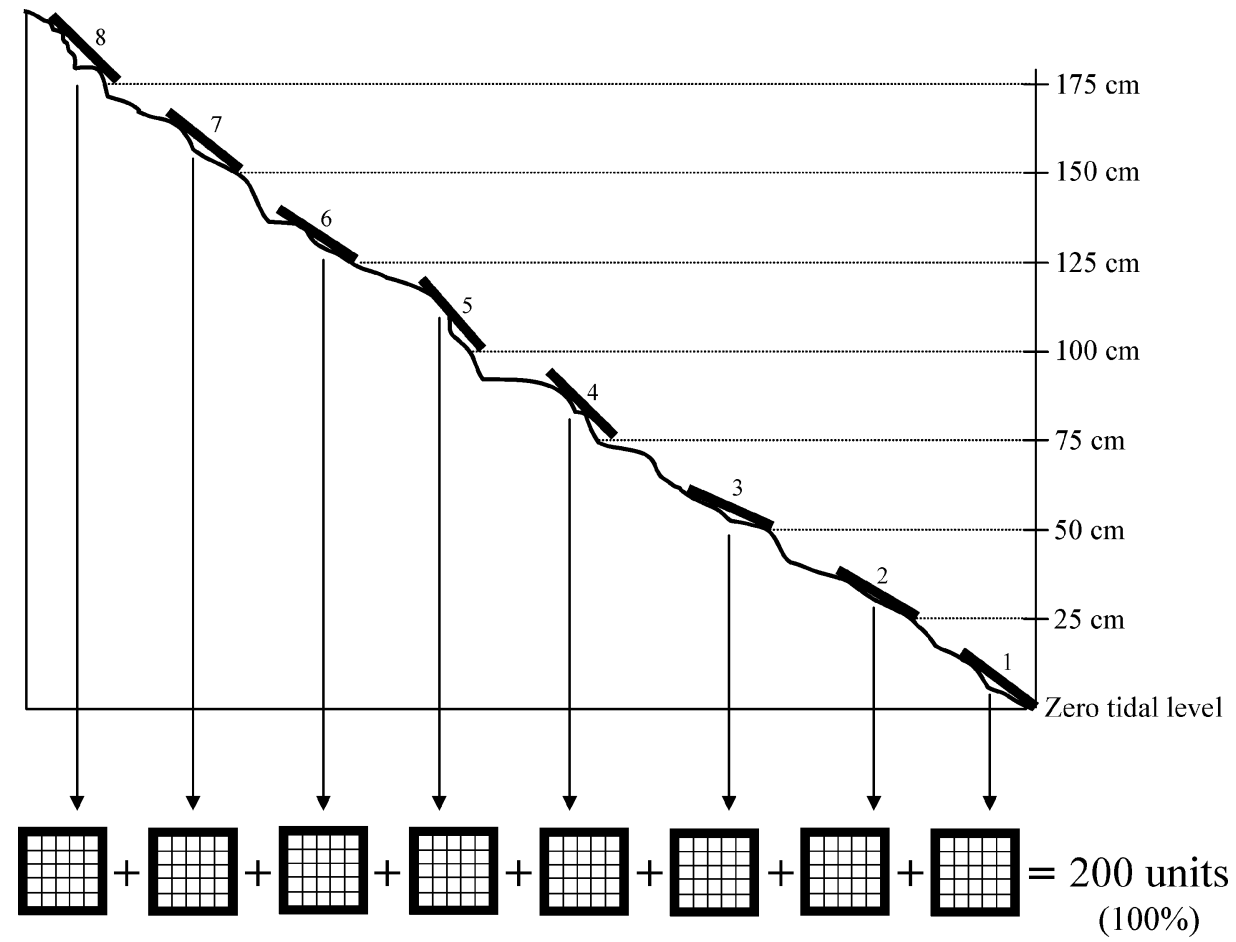

Figure 2. Sampling design conducted in each transect. Four transects were sampled for each locality.

dissolved oxygen was measured using an oxymeter WTW oxi-196, and turbidy was measured in nephelometric turbidy units (ntu) using a turbidimeter Hanna HI 93703.

\subsection{Statistics}

Taking into account that the objective of the present study is the comparison among sampling localities and not a detailed descriptive study of the different belts (heights) in each transect, the eight quadrats of each transect (Figure 2) were added, and considered as a whole area of 200 units per transect ( 25 units per square, and a total of 8 square per transect). Consequently, the data of abundance (expressed in frequency percentages) of species were calculated based on the presence/absence in 200 units distributed along the 2 meters vertical transect (Figure 2). This method, although involving a lost of information regarding to the different heights (belts) inside each transect, it is useful to characterise each sampling locality intertidal zone as a whole and get an integrated matrix with single data for each species in each transect (4 values for each sampling site) instead of getting 8 data (one for each height) for each species in each transect. 


\subsubsection{Univariate Analysis}

The total number of species $(\mathrm{S})$, the Shannon-Wiener diversity index $\left(\mathrm{H}^{\prime}\right)$ (Shannon and Weaver, 1963) and Pielou's evenness index (J) (Pielou, 1966) were calculated for each transect. Mean values of the four transects sampled in each locality and standard deviation values were calculated. Possible differences in these indices between internal and external sites were tested using the KruskalWallis test, after verifying that hypothesis of normality (Kolmogorov-Smirnov test) was not passed; Levene's test showed homogeneity of variances, indicating that the Kruskal-Wallis test was adequate. For multiple post-hoc comparisons we used the Tamhane's test. For univariate analyses, the BMDP was used (Dixon, 1983).

\subsubsection{Multivariate Analysis}

The affinities among stations based on the environmental parameters were established through cluster analysis using UPGMA (unweighted pair group method using arithmetic averages) (Sneath and Sokal, 1973) and euclidean distances. Abiotic data were $\log (x+1)$ transformed (Guerra-García et al., 2003). The affinities among transects based on biotic data were also established through cluster analysis using UPMA method, based on the Bray-Curtis similarity index (Bray and Curtis, 1957). The relationships between environmental measures and biotic assemblages were studied by Canonical Correspondence Analysis (CCA). This analysis is a direct gradient technique in which the resulting ordenation of stations is directly related to the values of the environmental factors (Ter Braak, 1986). Relationships between multivariate biological structure and environmental variables were also examined using the BIO-ENV procedure (Clarke and Ainsworth, 1993). Percentage of similarity analysis (SIMPER) (Clarke, 1993) was used to determine the species involved in grouping of the different sampling localities. Multivariate analyses were carried out using the PRIMER package (Clarke and Gorley, 2001) and the PC-ORD programme (McCune and Mefford, 1997).

\section{Results and Discussion}

\subsection{ENVIRONMENTAL VARIABLES}

The general trend of the abiotic variables throughout the bay is shown in Figure 3. Temperature, $\mathrm{pH}$ and salinity present similar values in all localities sampled. Turbidity was higher inside the bay than in external localities, while dissolved oxygen concentrations were higher in the external sites. This is the expected trend in Algeciras Bay, since the configuration of the bay involves less water renovation inside than outside the bay; these results are in agreement with our previous studies conducted in Algeciras Bay which showed that the prevailing 

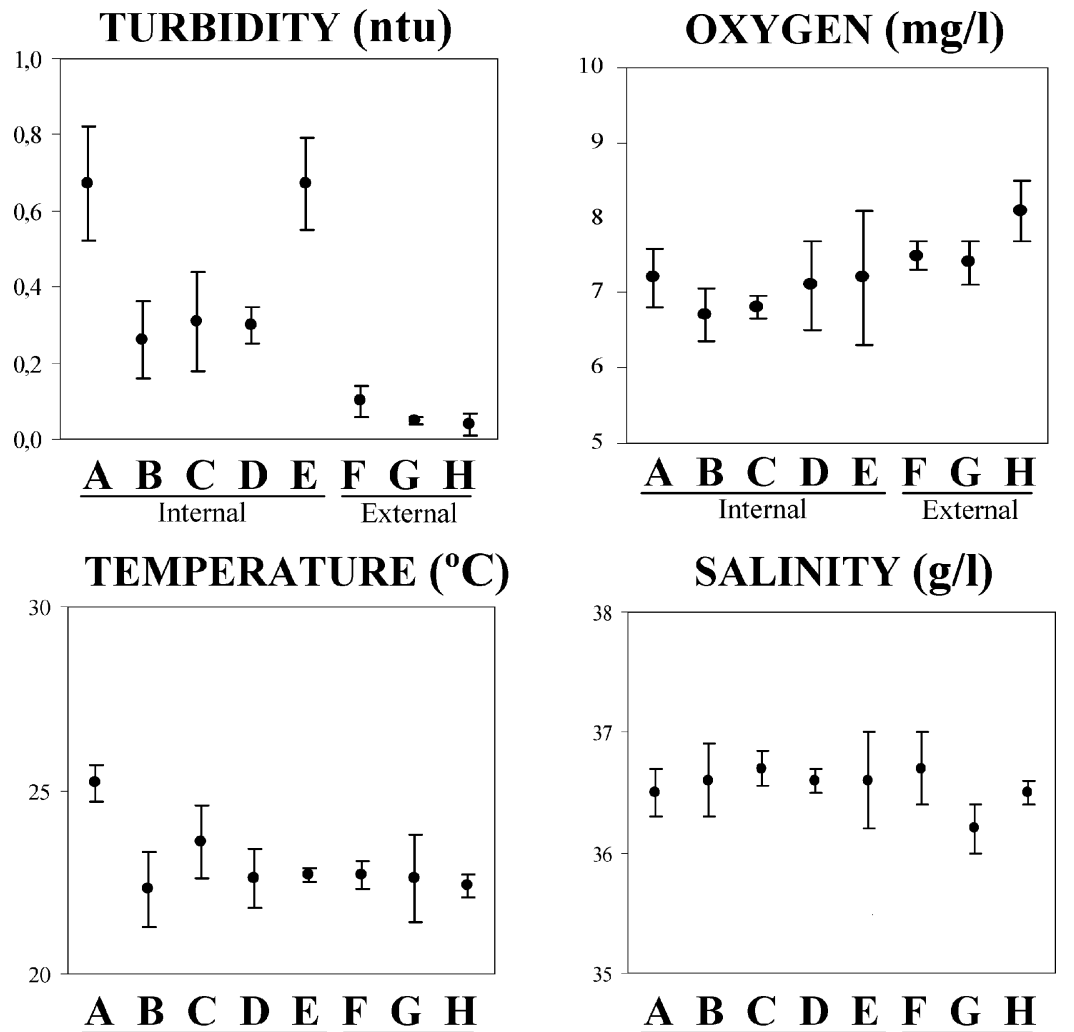

Internal External

$\frac{\text { A B C D E }}{\text { Internal }} \frac{\mathbf{F} \mathbf{H}}{\text { External }}$

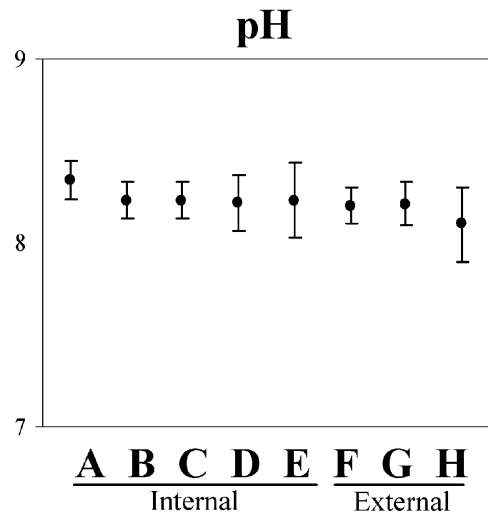

Figure 3. Mean values and standard deviations $(n=3)$ of abiotic parameters measured in the present study.

conditions in the external zone are high hydrodynamics and low sedimentation rate, whereas the internal zone presents high sedimentation rate and higher values for organic matter (Carballo et al., 1996; Naranjo et al., 1996; Sánchez-Moyano et al., $2002 a, b)$. 


\subsection{Distribution OF FAUnA AND AlgAe}

The eight stations provided a total of 57 identified taxa, of which 22 were macrofauna, and 35 algae. Table I shows the overall dominance in the four transects (1-4) of the eight stations $(\mathrm{A}-\mathrm{H})$.

Most of the common species of macrofauna were widely distributed throughout the bay, such as the cirripeds Chtamalus stellatus and Balanus perforatus, and the molluscs Littorina littorea, Littorina neritoides, Mytilus cf edulis, Patella caerulea, Patella rustica, Patella nigra and Siphonaria pectinata. Especially remarkable is the presence of the endangered mollusc Patella ferruginea in the stations B and G. The limpet Patella ferruginea Gmelin, 1791 is the most endangered marine invertebrate in the western Mediterranean rocky shores (Laborel-Deguen et al., 1991a; Ramos, 1998). Although its relative abundance in Palaeolithic and Neolithic deposits indicates an extensive former distribution in the western Mediterranean Basin (east coast of Italy, Mediterranean France, Iberian Peninsula, Morocco, Tunisia and the western Mediterranean islands), today its Mediterranean range has progressively contracted to a few restricted areas (Fischer-Piette, 1959; Cretella et al., 1994; Templado, 1996) probably due to human pressure (Aversano, 1986). Although recently, several important populations of $P$. ferruginea have been found and studied in Ceuta, North Africa (Guerra-García et al., 2004a, b), the presence of this species in the Iberian Peninsula is extremely reduced; the most recent cites of $P$. ferruginea in the Iberian Peninsula were reported by García-Gómez (1983) who recorded the species in Algeciras Bay, and Moreno (1992), who found two specimens in Cabo de Gata. Several specimens have been recently observed in the Gibraltar harbour by Templado and $\mathrm{Fa}$ in 2002 (pers. comm.). Consequently, it would be advisable to undertake a further study of these populations of $P$. ferruginea in the internal and external zone of Algeciras Bay in the near future. Little is known about the biology of $P$. ferruginea so far; this species has a very low growth and reproductive rate, reaching sexual maturity at the age of 2-3 years. It is a protandric species with relatively large sized ovocites suggesting a short planktonic phase (Frenkiel, 1975; Templado, 1996), it is considered a k-strategist (Laborel-Deguen et al., 1991b) and feeds mainly on cyanobacteria and the algae Ralfsia spp. and Rissoella spp.

In contrast to macrofauna, the algae showed greater discrimination between internal and external sites (Table I). Although some species were very common throughout the bay (e.g. Corallina elongata, Ceramium rubrum, Gelidium pusillum, Hildenbrandia sp. and Ulva rigida), the external localities San García (F, G) and Punta Carnero (H) were clearly richer in number of species than the internal sites. Species such as Bryopsis plumosa, Caulacanthus ustulatus, Codium adherens, Cladophora spp., Fucus spiralis, Lithophyllum lichenoides and Rivularia bullata, were exclusively distributed in these external sites, and other species such Asparagopsis armata, Colpomenia sinuosa, Gelidium latifolium and Mesophyllum lichenoides, although present in some internal sites, were much more abundant in the external localities. 


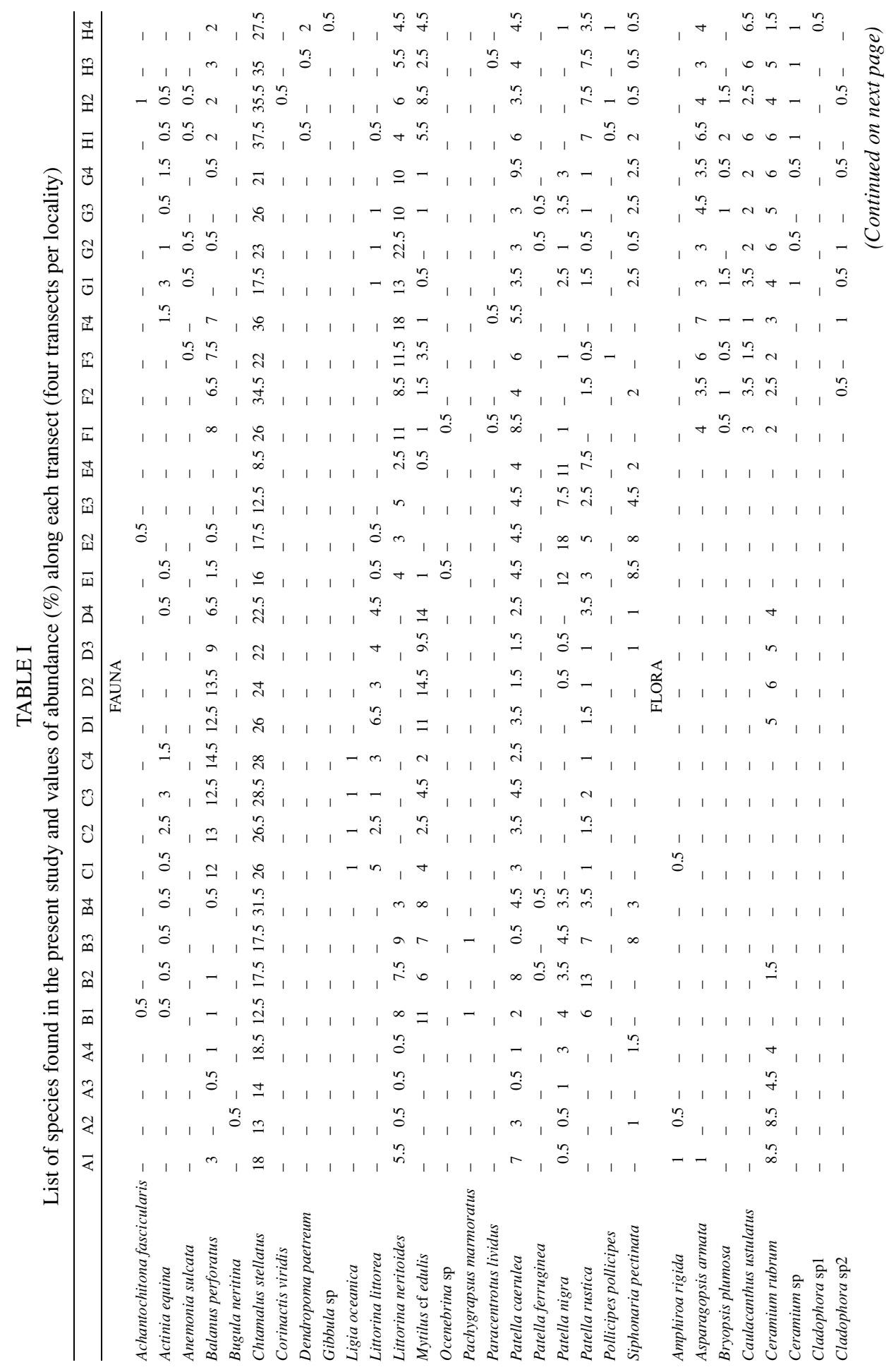




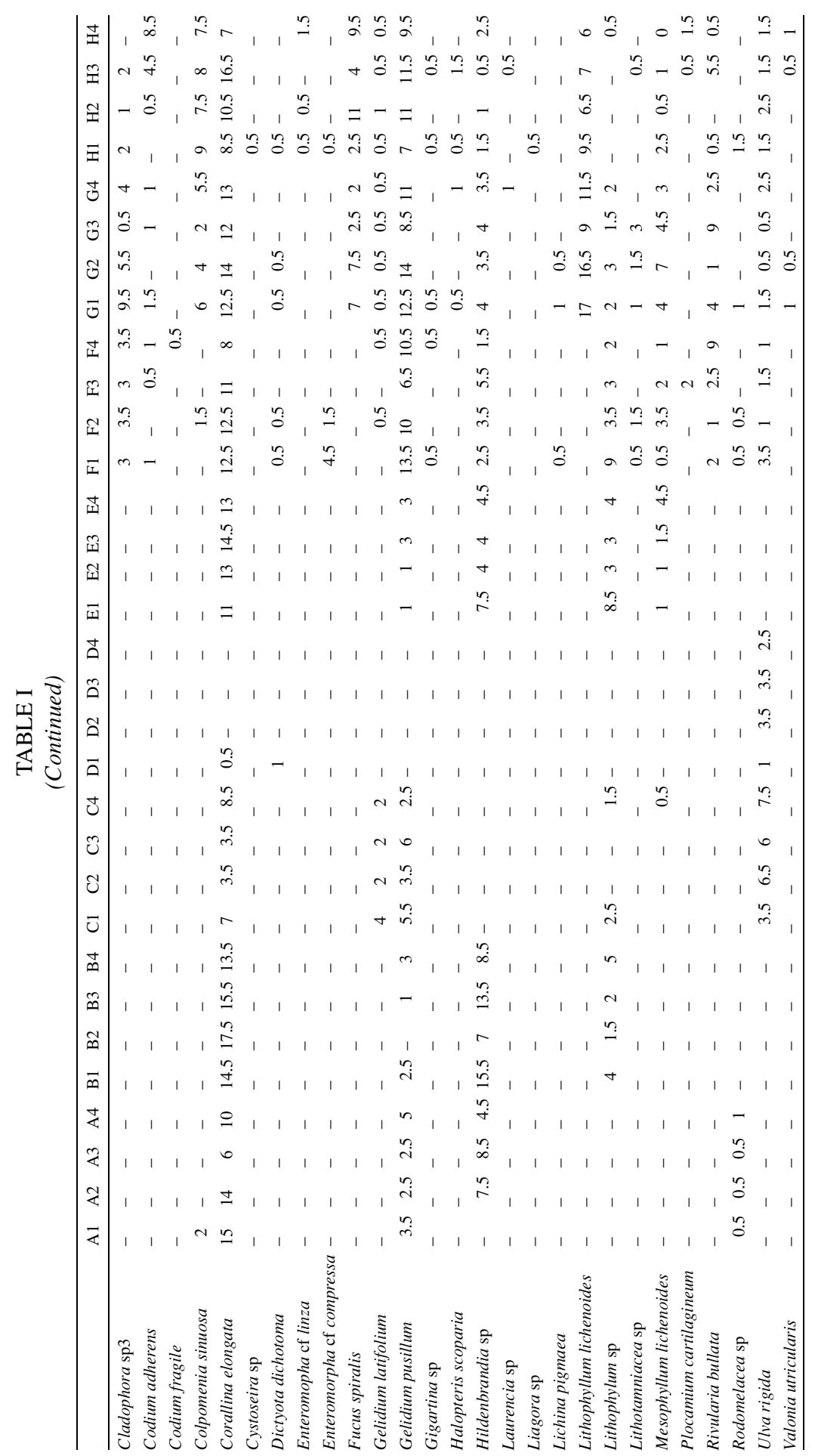



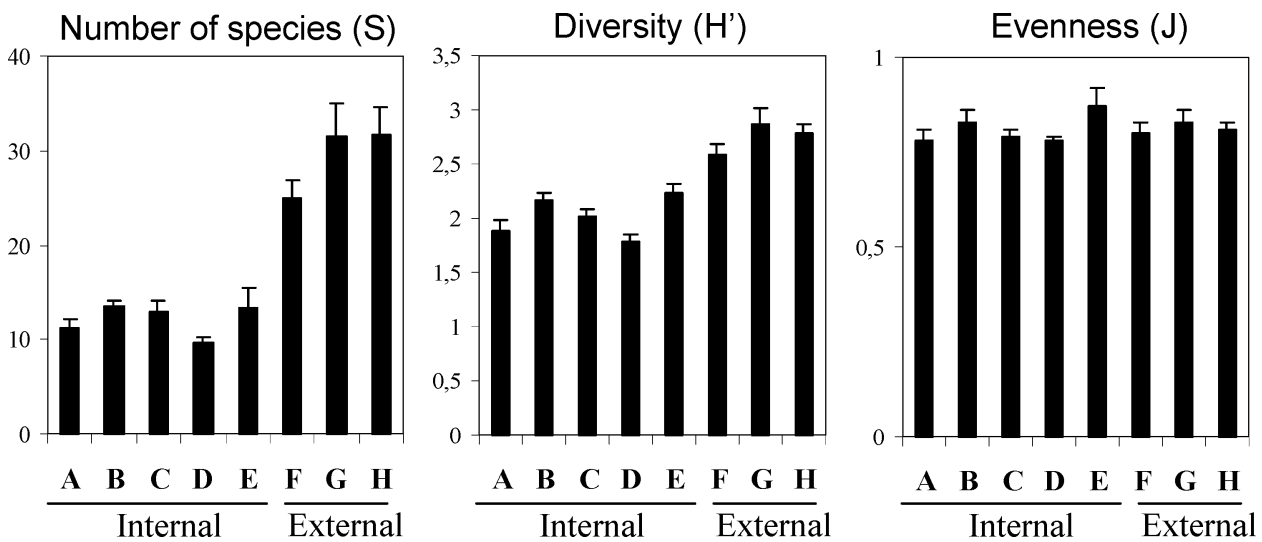

Figure 4. Mean values and standard deviations ( $n=4$ transects) of descriptive parameters in each sampling locality.

Confirming the above trend, the mean values of number of species and diversity per locality were significantly higher in the external sites $(\mathrm{F}-\mathrm{H})$ than in the internal localities (A-E) (Figure 4 and Table II). The number of species clearly differentiated the two groups of sites (external $v s$ internal); however the evenness values were similar in all the localities and no statistical differences could be obtained (Table II). This similarity in evenness values determined that Shannon diversity values, although higher in external sites, were not as discriminative than the number of species.

These differences of species richness and diversity between internal and external sites, shown by the univariate analysis based on the study of the intertidal community, are in agreement with previous studies focused in subtidal communities of Algeciras Bay. For example, Conradi et al. (1997) showed that the amphipod population associated with the bryozoan Bugula neritina had a higher diversity and species richness in the stations located at the mouth of the bay than the inner

TABLE II

Results of the Kruskal-Wallis for the data of number of species, diversity $\left(\mathrm{H}^{\prime}\right)$ and evenness (J)

\begin{tabular}{lll}
\hline & $K$ & Homogeneous group \\
\hline Number of species & $28.06^{* * *}$ & $\underline{\mathrm{A} \mathrm{B} \mathrm{CDE}} \underline{\mathrm{FGH}}$ \\
Diversity $\left(H^{\prime}\right)$ & $29.34^{* * *}$ & $\underline{\mathrm{AD}} \underline{\mathrm{BCE}} \underline{\mathrm{FGH}}$ \\
Evenness $(J)$ & $16.17 \mathrm{n} . \mathrm{s}$. & $\underline{\mathrm{A} \mathrm{B} \mathrm{DEFGH}}$ \\
\hline
\end{tabular}

Note. n.s., not significant, ${ }^{* * *} p<0.001$. The homogeneous group according to the Tamhane's test $(p<0.05)$ are indicated underlined with a continuous line. 
stations with low water movement and higher sedimentation. Sánchez-Moyano and García-Gómez (1998) and Sánchez-Moyano et al. (2002a, b) studied the spatiotemporal distribution of the epifaunal community of macrofauna living on the alga Halopteris scoparia, collected by scuba in several stations of Algeciras Bay, and reported that in the external zone a greater number of species appeared. Carballo et al. (1996) and Naranjo et al. (1996) exploring the value of sponges and ascidians, respectively, as marine bioindicators in Algeciras Bay, also found significantly richer number of species and diversity values in the external sites of San García and Punta Carnero.

\subsection{Multivariate AnAlysis}

The cluster analysis using the environmental matrix of abiotic parameters showed that the two groups of localities (external $v s$ internal) could be differentiated (Figure $5 \mathrm{~A}$ ), mainly based on the low values of turbidity and high values of dissolved
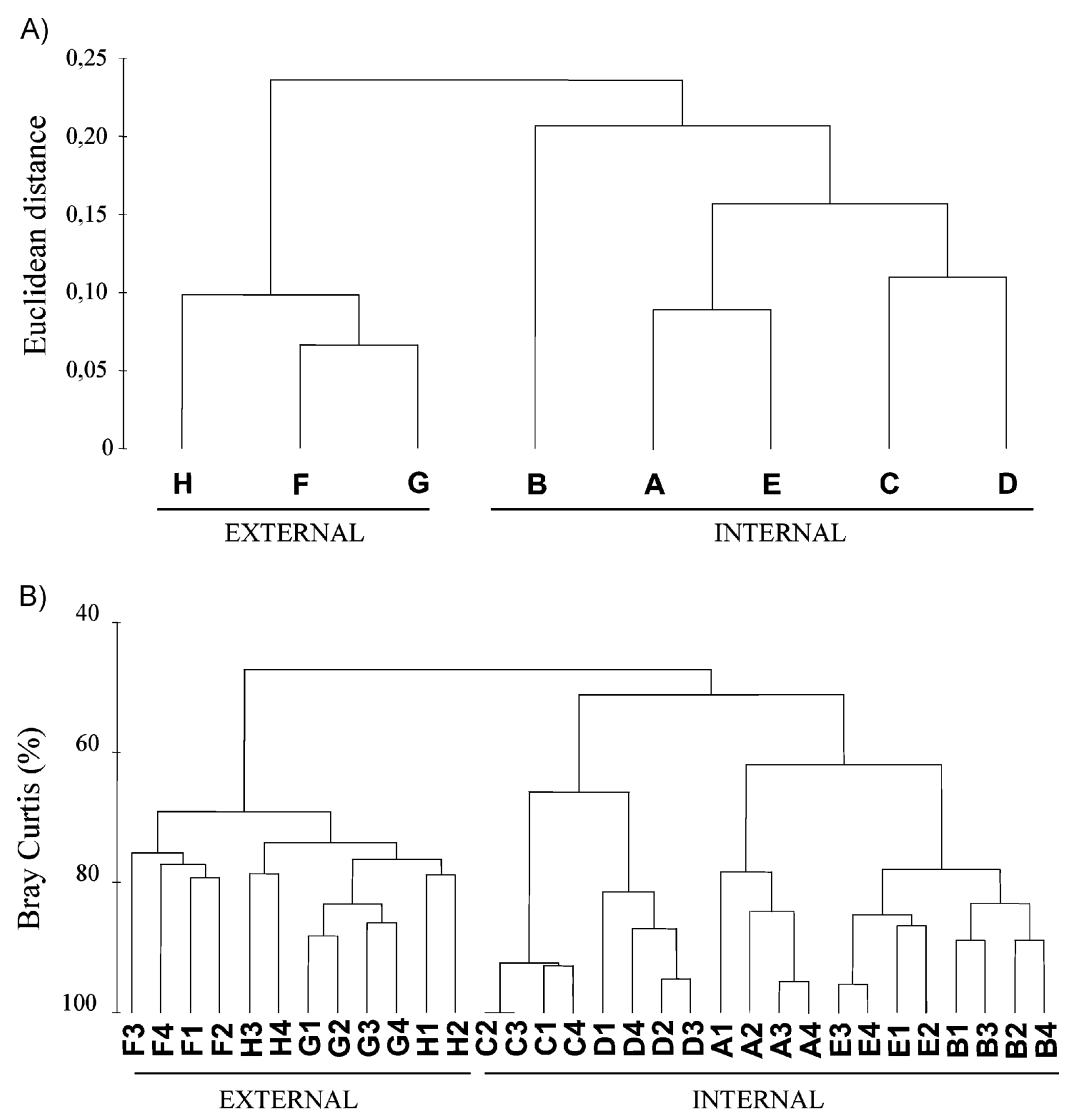

Figure 5. Dendrograms of similarity between the stations. (A) based on the environmental data; (B) based on the species composition. 
oxygen in the external sites F-H (Figure 3). The cluster analysis based on the abundance values of the intertidal community species of the four transects in each locality (Figure 5B) was very similar to that obtained with the abiotic parameters and showed two groups of stations. The first group included the external sites (F$\mathrm{H}$ ), characterised by high values of species richness and diversity, and the second group included the remaining sites. This group, was divided into two subgroups; one of them including the transects of the harbour sites $(C, D)$ and the other one including the remaining transects (A, B, E). The sampling sites $\mathrm{C}$ and D were located within the harbour walls and the waves produced by the ferries and boats moving across the harbour could influence the species composition of the intertidal communities of these two sites.

When the SIMPER analysis was applied to detect the species contributing most to the dissimilarity between the two groups of stations (A-E: internal vs. F-H: external), the outstanding organisms were the molluscs Chtamalus stellatus and Littorina neritoides, and the alga Gelidium pusillum, all of them more abundant in the external sites. The whole list of taxa listed in order of decreasing contribution to the average dissimilarity between the two groups of sites up to $90 \%$ of accumulated total dissimilarity is included in Table III.

The Canonical Correspondence Analysis (CCA) confirmed the ordination of the localities previously obtained by the Cluster analysis. The external sites $(\mathrm{F}-\mathrm{H})$ appeared together in the positive part of axis 1 and negative part of axis 2, mainly determined by higher oxygen concentrations (Figure 6). Sites C and D, located within the harbour walls, were also grouped apart, and the remaining stations were characterised by higher values of turbidity. Axis 1 seems to separate the stations according to the oxygen and salinity gradient, and axis 2 is mainly correlated with the water turbidity. This parameter, which showed the highest correlation in the CCA analysis (Table IV), seems to be one of the most important factor affecting algae and macrofauna distribution. In fact, according to the BIO-ENV analysis, the best combination to explain the biological data was a single variable, turbidity $(r=0.40)$. Consequently, turbidity seems to be an interesting parameter to take into account in future environmental control programmes conducted in Algeciras Bay. This measure is easily and quickly undertaken with a turbidimeter, it is strongly related to the amount of solids in suspension (pers. obs.) and it is much quicker to obtain than the estimation of suspension solids by filtering water (see Guerra-García and García-Gómez, 2001).

\subsection{Conclusions AND ENVIRONMENTAL IMPLiCATIONS FOR FUtURE PROGRAMMES OF MONITORING}

Authorities and Governmental Institutions are increasingly demanding quick and effective environmental studies in coastal areas, as useful tools for monitoring programmes. This fact precludes developing series of data based on complex matrices of various taxonomic groups whose identification requires great effort and time. 
TABLE III

Average abundances of the most relevant species of the sampling sites located in the internal area of Algeciras Bay (A-E) (INT) and external area (F-H) (EXT)

\begin{tabular}{lcccccc}
\hline Taxa & Abund. INT. & Abund. EXT. & Av. dis. & Ratio & Dis.\% & Cum. dis\% \\
\hline Chtamalus stellatus & 20.03 & 28.46 & 4.83 & 1.56 & 9.28 & 9.28 \\
Littorina neritoides & 2.45 & 10.38 & 4.24 & 1.82 & 8.13 & 17.41 \\
Gelidium pusillum & 2.28 & 10.46 & 4.17 & 4.68 & 8.00 & 25.41 \\
Balanus perforatus & 5.13 & 3.25 & 2.59 & 1.27 & 4.98 & 36.92 \\
Corallina elongata & 9.03 & 11.50 & 2.36 & 1.11 & 4.53 & 41.45 \\
Mytilus cf edulis & 4.78 & 2.54 & 2.23 & 1.21 & 4.29 & 45.74 \\
Asparagopsis armata & 0.05 & 4.33 & 2.20 & 4.68 & 4.22 & 49.96 \\
Colpomenia sinuosa & 0.10 & 4.25 & 2.06 & 1.30 & 3.95 & 53.91 \\
Fucus spiralis & 0.00 & 3.83 & 1.89 & 1.30 & 3.63 & 57.54 \\
Hildenbrandia sp & 4.25 & 2.79 & 1.83 & 1.53 & 3.52 & 61.06 \\
Patella nigra & 3.50 & 1.08 & 1.68 & 0.80 & 3.22 & 64.28 \\
Caulacanthus ustulatus & 0.00 & 3.29 & 1.66 & 2.41 & 3.19 & 67.47 \\
Rivularia bullata & 0.00 & 3.13 & 1.60 & 2.69 & 3.08 & 70.55 \\
Cladophora sp3 & 0.00 & 3.13 & 1.60 & 2.07 & 3.06 & 73.61 \\
Ceramium rubrum & 2.35 & 3.92 & 1.52 & 1.98 & 2.92 & 76.53 \\
Patella rustica & 3.00 & 2.63 & 1.49 & 1.24 & 2.85 & 79.38 \\
Mesophyllum lichenoides & 0.43 & 2.46 & 1.11 & 1.42 & 2.13 & 81.51 \\
Lithophyllum sp & 1.75 & 2.21 & 1.08 & 1.25 & 2.07 & 83.58 \\
Ulva rigida & 1.70 & 1.58 & 1.02 & 1.70 & 1.96 & 85.55 \\
Patella caerulea & 3.33 & 5.08 & 0.93 & 1.58 & 1.78 & 87.33 \\
Siphonaria pectinata & 1.93 & 1.13 & 0.86 & 1.00 & 1.65 & 88.97 \\
Codium adherens & 0.00 & 1.63 & 0.81 & 1.29 & 1.56 & 90.53 \\
\hline Nore. Species are & & & & & \\
\hline
\end{tabular}

Note. Species are listed in order of decreasing contribution to the average dissimilarity (Av. dis.) between the two groups up to $90 \%$ of accumulated total dissimilarity (Cum. dis \%). The ratio indicates Dis/Standard deviation. The total average dissimilarity between groups is $52.1 \%$.

In Algeciras Bay, several studies had been conducted previously to test the value of subtidal communities as bioindicator of environmental conditions. These studies had been focused on subtidal epifauna living on algae or bryozoans, and subtidal sponges or ascidians. In both cases, scuba diving was necessary for sampling and great efforts were required for identification due to the difficulties in taxonomy of epifaunal groups of molluscs, polychaetes and crustaceans, and also in sponges or ascidians. All these previous studies showed strong correlation between spatial distribution of biological taxa and the environmental parameters measured, and differentiated the external versus the internal sites in Algeciras bay based on the faunal composition. In the present study we have tested the values of intertidal communities as bioindicators in the same environment as the previous studies, 


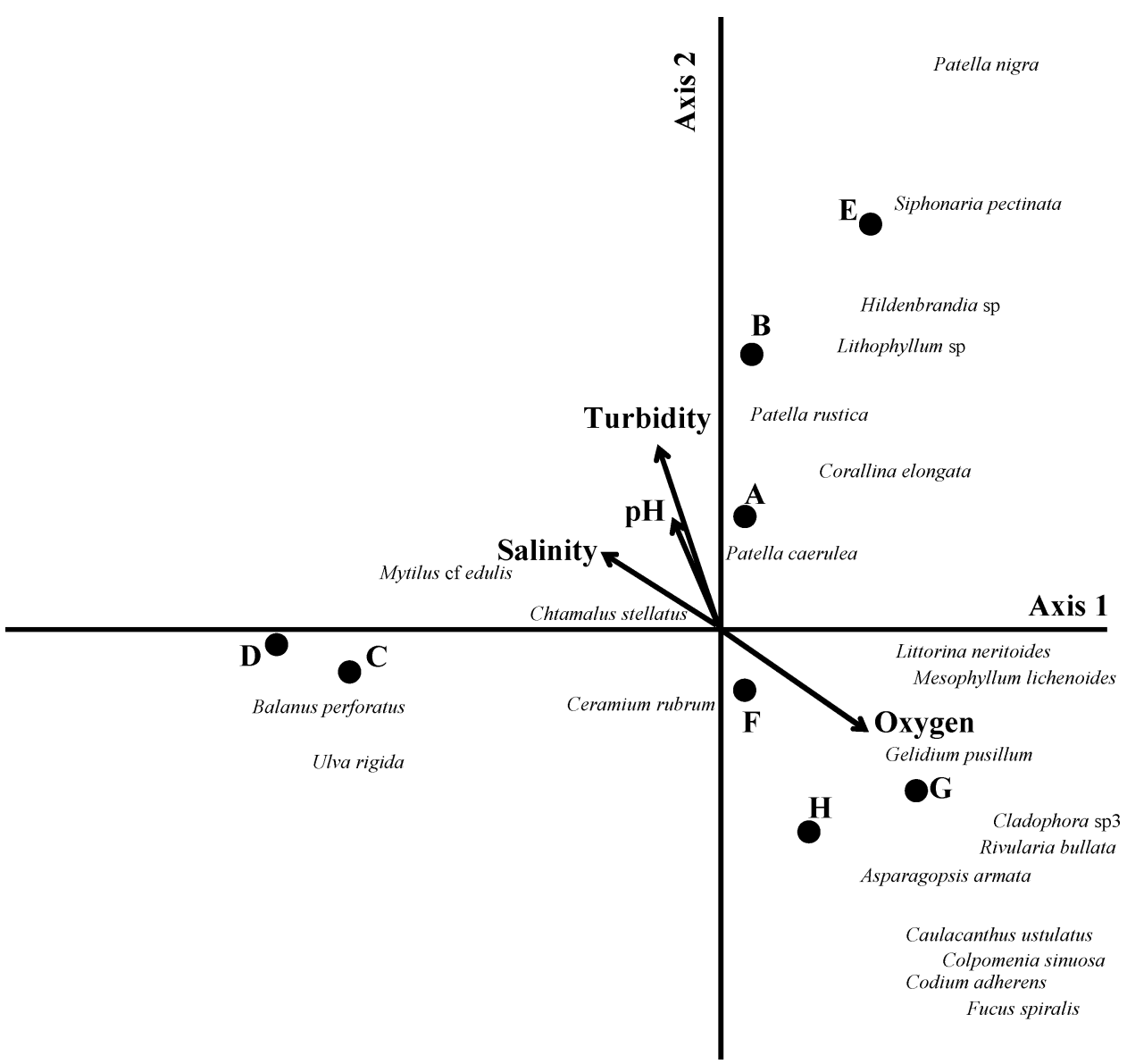

Figure 6. Graph representation of the localities and species with respect to the first two axes of the Canonical Correspondence Analysis (CCA). The species included are those which most contributed to the dissimilarity between internal and external sites according to the Simper (Table III). See also Table IV.

Algeciras Bay, and we have obtained similar results: a good correlation between environmental measures and biotic data, and a clear separation between internal and external sites based on the biotic data. However, we should also consider that there may be circumstances where the use of one habitat or the other could be preferable (e.g. an oil spill near shore would suggest intertidal monitoring, but discharge of non-buoyant effluent from a submarine outfall might be better monitored subtidally).

The method used in the present study (Figure 2) does not require scuba diving, and is based only on the most distinct and conspicuous species of alga and sessile macrofauna (epifaunal community is not considered). Consequently, the spatial study of the intertidal communities following the sampling method proposed in 
TABLE IV

Summary results of the canonical correspondence analysis

\begin{tabular}{lccc}
\hline & Axis 1 & Axis 2 & Axis 3 \\
\hline Species-environment correlation & 0.99 & 0.99 & 0.99 \\
Percentage of species variance & 33.7 & 28.4 & 11.4 \\
\multicolumn{4}{r}{ Correlation with environmental variables } \\
Turbidity & - & 0.77 & - \\
Oxygen & 0.44 & -0.56 & - \\
Salinity & -0.52 & - & - \\
pH & - & 0.49 & - \\
\hline
\end{tabular}

Note. Only environmental variables significantly correlated with CCA axes at $p<0.05$ are included.

this study is presented here as an alternative strategy and it can be a useful tool to characterise the interest of a site from a biotic point of view. Since this kind of sampling is less demanding in terms of time and resources than others currently in use, this method can easily be repeated periodically to detect natural or anthropogenic alterations in the intertidal community. Therefore, this tool could be useful for monitoring purposes. For example, Algeciras harbour is currently begining to be affected by considerable remodelation which is surely affecting the communities of the whole bay. We plan to use the method proposed herein as a control method for monitoring the environmental conditions of Algeciras Bay during the remodelation of the harbour, or to detect changes due to accidental oil spills since there is intense marine traffic in the bay. This study reflects that a spatial approach dealing with the most distinctive species of intertidal communities can yield similar results to those obtained with costly physico-chemical analysis and based on complex matrices of epifaunal communities.

\section{Acknowledgments}

Thanks are due to R. Gálvez for helping during the sampling programme, and to M.P. Chatterley for the English revision of the manuscript. We are very grateful to the harbour authority 'Autoridad Portuaria de la Bahía de Algeciras' for the financial support of this study.

\section{References}

Aversano, F. R.: 1986, 'Esperimento di insediamento artificiale di Patella ferruginea Gmelin, 1791 nelle acque del Golfo di Arzachena (Sardegna settentrionale)', Boll. Malacol. 22, 169-170. 
Bray, J. R. and Curtis, J. T.: 1957, 'An ordenation of the upland forest communities of Southern Wisconsin', Ecol. Monogr. 27, 325-349.

Cai, L. Z., Tam, N. F. Y., Wong, T. W. Y., Ma, L., Gao, Y. and Wong, Y. S.: 2003, 'Using benthic macrofauna to assess environmental quality of four intertidal mudflats in Hong Kong and Shenzhem', Acta Oceanol. Sinica 22, 309-319.

Carballo, J. L., Naranjo, S. A. and García-Gómez, J. C.: 1996, 'Use of marine sponges as stress indicators in marine ecosystems at Algeciras Bay (southern Iberian Peninsula)', Mar. Ecol. Prog. Ser. 135, 109-122.

Clarke, K. R.: 1993, 'Non-parametric multivariate analyses of changes in community structure', Aust. J. Ecol. 18, 117-143.

Clarke, K. R. and Ainsworth, M.: 1993, 'A method of linking multivariate community structure to environmental variables', Mar. Ecol. Prog. Ser. 92, 205-219.

Clarke, K. R. and Gorley, R. N.: 2001, Primer v5: User Manual /Tutorial. Primer-E, Plymouth, pp. $1-91$.

Conradi, M., López-González, P. J. and García-Gómez, J. C.: 1997, ‘The Amphipod community as a bioindicator in Algeciras Bay (Southern Iberian peninsula) based on a spatio-temporal distribution', P.S.Z.N.: Mar. Ecol. 18, 97-111.

Cretella, M., Scillitani, G., Toscano, F., Turella, P., Picariello, O. and Cataudo, A.: 1994, 'Relationships between Patella ferruginea Gmelin, 1791 and the other Tyrrhenian species of Patella (Gastropoda: Patellidae)', J. Moll. Stud. 60, 9-17.

Dixon, W. J.: 1983, BMDP Statistical Sofware. University California Press, Berkeley.

Fa, D. A.: 1990, A diversity-based comparative study of the rocky coasts of Gibraltar, Unpublished Undergraduate Thesis, St. Mary's College, Twickenham, UK.

Fa, D. A., Finlayson, C., García-Adiego, E., Sánchez-Moyano, J. E. and García-Gómez, J. C.: 2002, 'Influence of some environmental factors on the structure and distribution of the rocky shore macrobenthic communities in the Bay of Gibraltar: Preliminary reults', Almoraima 28, 73-88.

Fischer-Piette, E.: 1959, 'Contribution à l'ecolologie intercotidale du Détroit de Gibraltar', Bull. L'Inst. Ocean. 1145, 1-32.

Frenkiel, L.: 1975, 'Contribution à l'étude des cycles de reproduction des Patellidae en Algérie', $P$. S. Z.N. 39, 153-189.

García-Gómez, J. C.: 1983, 'Estudio comparado de las tanatocenosis y biocenosis malacológicas del Estrecho de Gibraltar y áreas próximas', Iberus 3, 75-90.

Guerra-García, J. M. and García-Gómez, J. C.: 2001, 'The spatial distribution of Caprellidea (Crustacea: Amphipoda): A stress bioindicator in Ceuta (North Africa, Gibraltar area)', P. S. Z. N. Mar. Ecol. 22, 357-367.

Guerra-García, J. M., González-Vila, F. J. and García-Gómez, J. C.: 2003, 'Aliphatic hydrocarbon pollution and macrobenthic assemblages in Ceuta harbour: A multivariate approach', Mar. Ecol. Prog. Ser. 263, 127-138.

Guerra-García, J. M., Corzo, J., Espinosa, F. and García-Gómez, J. C.: 2004a, 'Assesing habitat use of the endangered marine mollusc Patella ferruginea (Gastropoda, Patellidae) in northern Africa: Preliminary results and implication for conservation', Biol. Conserv. 116, 319-326.

Guerra-García, J. M., Corzo, J., Espinosa, F., Fa, D. A. and García-Gómez, J. C.: 2004b, 'Extinction risk and harbours as marine reserves?', J. Moll. Stud. 70, 96-98.

Jones, W. E., Bennell, S. J., Beveridge, C., McConnell, B, Mack-Smith, S., Mitchel, J. and Fletcher, A.: 1980, 'Methods of data collection and processing in rocky intertidal monitoring', in: J. H. Pryce, D. E. G. Irvine and W. F. Farnham (eds), The Systematics Association Special Volume. The Shore Environment: Methods, Academic Press, London, England, pp. 137-170.

Laborel-Deguen, F. and Laborel, J.: 1991a, 'Statut de Patella ferruginea Gmelin en Méditerranée', in: C. F. Boudouresque, M. Avon and V. Gravez (eds), Les spèces marines à protéger en Méditerranée, GIS Posidonie Publishers, Marseille, pp. 91-103. 
Laborel-Deguen, F. and Laborel, J.: 1991b, 'Nouvelles observations sur la population de Patella ferruginea Gmelin de corse', in: C. F. Boudouresque, M. Avon and V. Gravez (eds.), Les spèces marines à protéger en Méditerranée, GIS Posidonie Publishers, Marseille, pp. 119-128.

McCune, B. and Mefford, M. J.: 1997, PC-ord. Multivariate Analysis of Ecological Data, Mjm Software Design, Gleneden Beach, USA, pp. 1-47.

Moreno, D.: 1992, 'Presencia de Patella ferruginea Gmelin, 1971 en el Cabo de Gata (Almería, SE España)', Cuadernos de Investigación Biológica, Bilbao 17, 71.

Naranjo, S. A., Carballo, J. L. and García-Gómez, J. C.: 1996, 'Effects of environmental stress on ascidian populations in Algeciras Bay (southern Spain). Possible marine bioindicators?', Mar. Ecol. Prog. Ser. 144, 119-131.

Pielou, E. C.: 1966, 'The measurement of diversity in different types of biological collections', $J$. Theor. Biol. 13, 131-144

Ramos, M. A.: 1998, 'Implementing the Habitats Directive for mollusc species in Spain', J. Conch. Spec. Publ. 2, 125-132.

Sánchez-Moyano, J. E. and García-Gómez, J. C.: 1998, 'The arthropod community, especially Crustacea, as a bioindicator in Algeciras Bay (Southern Spain) based on a spatial distribution', $J$. Coastal Res. 14, 1119-1133.

Sánchez-Moyano, J. E., Estacio, F., García-Adiego, E. M. and García-Gómez, J. C.: 2000a, 'The molluscan epifauna of the alga Halopteris scoparia in Southern Spain as a bioindicator of coastal environmental conditions', J. Moll. Stud. 66, 431-448.

Sánchez-Moyano, J. E., García-Adiego, E. M., Estacio, F. and García-Gómez, J. C.: 2000b, 'Effect of environmental factors on the spatial distribution of the epifauna of the alga Halopteris scoparia in Algeciras Bay, Southern Spain', Aquatic Ecol. 34, 355-367.

Sánchez-Moyano, J. E., García-Adiego, E. M., Estacio, F. and García-Gómez, J. C.: 2002, 'Effect of environmental factors on the spatial variation of the epifaunal polychaetes of the alga Halopteris scoparia in Algeciras Bay (Strait of Gibraltar)', Hydrobiologia 470, 133-148.

Shannon, C. E. and Weaver, W.: 1963, The Matematical Theory of Comunications. University of Illinois Press, Urbana, Illinois. 117 pp.

Sneath, P. H. A. and Sokal, R. R.: 1973, Numerical Taxonomy. The Principles and Practice of Numerical Classification, WH Freeman and Company, San Francisco, pp. 1-573.

Templado, J.: 1996, 'Patella ferruginea', in: M. A. Ramos (ed.), Inventario de las especies de invertebrados no artrópodos incluidas en los anejos de la Directiva 92/43/CEE del Consejo, ICONA, Spain, pp. 1-15.

Ter Braak, C. J. F.: 1986, 'Canonical Correspondence Analysis: A new eigenvector technique for multivariate direct gradient analysis', Ecology 67, 1167-1179.

Thompson, R. C., Crowe, T. P. and Hawkins, S. J.: 2002, 'Rocky intertidal communities: past environmental changes, present status and predictions for the next 25 years', Environ. Conserv. 29, 168-191. 